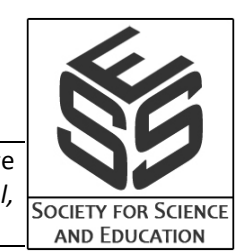

\title{
Teachers` level of support in the use of teaching and learning resources of learners who are physically challenged in regular primary Schools in Kisumu West Sub County, Kenya.
}

\author{
Dorine Adhiambo Obara \\ Maseno University, P.0 Box 333, Maseno, Kenya. \\ Charles Michael Were \\ Maseno University, P.0 Box 333, Maseno, Kenya.
}

\begin{abstract}
The Government of Kenya made inclusive education a policy requirement in the provision of education to all children. Research has shown that the support given by teachers plays a very important role in curriculum implementation that ensures success in a child s career. Education Assessment records in Kisumu county indicate that between the year 2012 and 2016, 846 learners who are physically challenged had been assessed and placed in regular schools in Kisumu West, Kisumu Central and Kisumu East sub-counties, out of which 246 had dropped out of school. However, Learners who are physical challenged often drop out of school more as compared to their regular counterparts particularly in Kisumu West Sub-County. The number of learners who are physically challenged enrolled in regular primary schools has been decreasing due to dropouts despite the fact that officers in Kisumu EARC conducted sensitization programs and workshops yearly for teachers and stakeholders in education. This decrease is confirmed at $138(31.9 \%)$, which is higher as compared to the dropout of neighboring sub-counties namely: Kisumu East 31 (21.8\%) and Kisumu Central 77(28.4\%). Reason for this high dropout has not been established. The purpose of this study was therefore to establish teachers' level of support in the use of teaching and learning resources of learners who are physically challenged in regular primary schools in Kisumu West Sub-County and objective of this study therefore was to establish teachers' level of support in the use of teaching and learning resources of learners who are physically challenged. A conceptual framework was used to show the interaction of dependent and independent variables. The study adopted descriptive survey research design. Target population of the study consisted of 15 head teachers, 30 teachers, 6 EARC coordinators and 90 learners who are physically challenged. Saturated sampling technique was used to select 13 head teachers and 4 EARC coordinators, while purposive sampling was used to select 27 teachers and 81 learners who are physically challenged. Data was collected using questionnaires, interview schedules and observation checklist. Face and content validity of instruments was established through expert judgment and revision. Reliability of instruments was established through test-retest method on $10 \%$ of study population using Pearson's product correlation. Reliability coefficient for head teachers questionnaire was 0.8 , teachers' questionnaires was 0.9 ; Learners who are physically challenged questionnaires was 0.7. This was above the accepted value of 0.7. Correlation coefficient analysis was used to establish teachers' level of support in the use of teaching and learning resources $f$ learners who are physically challenged. Quantitative data was analyzed using frequency counts, percentages and mean. Qualitative data from interview and observation schedules were collected, organized and categorized into themes and sub-themes, which were reported. Findings of the study indicated that most regular primary schools did not have adequate adapted teaching and learning resources required for learners who are physically challenged. The study recommended that Ministry of Education should ensure adequate supply of adapted
\end{abstract}


teaching and learning resources, Findings of this study would be useful to teachers, EARC coordinators, and Ministry of Education.

Key words: Level of support, Learning resources, Physically challenged, Learners.

\section{BACKGROUND TO THE STUDY}

In the field of Education, TLM is a commonly used acronym that stands for "teaching and learning resources." Broadly, the term refers to a spectrum of educational materials that teachers use in the teaching and learning process. They may include charts, model, text books, overhead projector, computers, classrooms and improvised materials. Due to their disabilities, learners who are physically challenged require more human and material resources for their education than their non-disabled peers. They need these resources at individual level as well as at classroom level, (M.O.E, 2003). Careful selection of teaching and learning resources contributes to nurturing concepts from basic ideas. They also help to download the often abstract concepts to understandable process (KICD, 2007). The effective implementation of curriculum calls for the provision of adequate and appropriate facilities, equipment and teaching and learning resources.

Moodley (2002) observed that in order for the learners to be active participants in the learning and teaching process, institutions must ensure that teaching and learning materials are used as well as made available to all the learners with special needs according to their needs. Research has shown that availability of learning materials can have substantive effect on curriculum implementation since learners remember $90 \%$ of what they say, see and do. They also help to download the often-abstract concepts to understandable process (Maina, 2009). Research on provision of services to learners with physical disability in inclusive classrooms in New Zealand by Bevan Brown in 2006; found that there was shortage of special education professionals and resources.

UNESCO (2004) points out that the learners must be provided with learning materials in formats that meet their individual needs. In an inclusive setting, learners would require other resources over and above what is provided by the school. These include resources to enhance mobility and communication such as wheel chairs, crutches, positioning devices, optical and non-optical devices and hearing devices (Randiki, 2002). In inclusion, it is emphasized that teachers should use locally available resources to support learning (Moodley, 2002). Making use of local artisans to repair the devices can also help in reducing the problem and make the educators able to deliver positively. This may improve the retention of learners who are physically challenged in the public institutions.

Leung and Mak (2010) investigated 51 Hong Kong primary school teachers' acceptance of inclusion. A large number of teachers (74.5\%) reported negative attitudes and expressed concerns about students' learning progress. They expressed a fear of increased difficulty in managing the classroom environment and also noted the insufficiencies relating to their schools' resources as well as limited support from the government. Hue (2012) reported that guidance teachers in secondary schools believed that students with particular types of special needs, needed to have more support and would be better educated in special schools. In summary, even though the concept of inclusion was introduced to Hong Kong a few decades ago, many regular primary and secondary teachers are not accustomed to including students with physical disability in their classroom (Poon-McBrayer, 2004).

World Bank (2012) found out that many African countries do not have enough resources to meet the demand of education. A report by all the Sub-Saharan conference on Education For All 
indicate that most countries in Africa experience shortage of all kinds of teaching and learning materials with difference in availability between rural and urban schools.

In Botswana, Research has concentrated on inclusion of learners with specific categories of disabilities. For example, Gaotlhobogwe (2001) explored the availability of learning support systems for inclusive education for learners with visual impairment. Recently, Brandon (2006), Kuyini and Mangope (2011) and Chhabra, Srivastava and Srivastava (2010) studied attitudes of teachers and student teachers 'towards inclusive education. These studies indicated that teachers in Botswana schools did not have favourable attitude towards inclusion for physically challenged learners. They were concerned about inadequate equipment and availability of paraprofessionals; additionally they raised concerns about provision of resources and funding to support the physically challenged learners in regular classrooms. The study concentrated on inclusion of learners with specific categories of disabilities. The current study was focusing on learners who are physically challenged in regular schools.

Momoh (2010) conducted a research on the effects of instructional resources on students' performance in West Africa School Certificate Examinations (WASCE). The achievements of students in WASCE were related to the resources available for teaching. His finding revealed that material resources have a significant effect on student's achievement as well as retention.

In Kenya, a Government Report on the National Conference of Education For All observed that in most primary schools in Kenya, pupils lack desks and chairs and the absence of these have diverse effects in learning (R.O.K, 1992). Ministry of Education Science and Technology. (2010) observes that there is inadequate provision of teaching and learning resources for learners with disabilities. The limited availability of curriculum support materials also limited the ability of the teachers to employ a variety of content teaching and learning activities for effective curriculum delivery. In the generalization of inclusive education the level of aid, support and expertise must be as per the demand. High cost of special equipment for learners with special needs is also hindrance towards realizing EFA; as a result there is inadequate provision of appropriate teaching and learning materials for learners who are physically challenged. This corresponds with Republic of Kenya (2005) and Ministry of Education (2009) stating that implementation of inclusive education in Kenya was compounded by lack of equipment and teaching/learning resources in teaching learners who are physically challenged in regular primary schools.

Karande (2014) in her study of factors influencing participation of learners with physical disability in public primary schools in Kiambu Municipality, used a study sample which constituted of 20 head teachers, 100 teachers and 43 learners with physical challenges totaling 143 respondents. She used descriptive research design and collected data by use of questionnaires and observation and schedules. The data was analyzed both quantitatively and qualitatively. Her findings revealed that majority of teachers were not trained in handling learners with physical disabilities resulting into learners not participating effectively in the learning process. The current study; however was to establish teachers` level of support in the use of teaching and learning resources for learners who are physically challenged in regular primary schools in Kisumu West Sub-County, Kenya.

\section{ASSISTIVE TECHNOLOGY}

This is an item, piece of equipment or product system whether acquired commercially of the shelf, modified or customized that is used to increase, maintain or improve the function capability of a child with disability. Technology has emerged as a means of mediating the environment for learners with SNE. Ringstaff and Kelley (2002), conducted a study in rural 
West Virginia at Hundred High School, on the impact of technology on academic success and showed favorable results. The school took advantage of a program called NET schools and received funding from the E-rate program. NET schools provided every student and teacher with a laptop. Once ports were installed, all the students and teachers connected to a Local Area Network. The results were astonishing. The desire to learn increased and students who had previously been disinterested in school became more active participants. After only six months, eighty percent of the students were accessing the Internet daily to gain supplemental instruction. In the past, their only source of information had been from the school library which contained out of date texts. Amuto (2002), such software make work easier on both the learners and the teachers, this also makes learning enjoyable and reduces stress on learners with visual impairments.

Moodley (2002) suggested that the availability of learning materials can have substantive effect on curriculum implementation. Leung and Mark (2010) focused on difficulty in managing the classroom environment and insufficiencies relating to their school's resources. Study by Ringstaff \& Kelly (2002), focused on the impact of technology on academic success. However, these studies did not focus on the teachers' level of support in the use of teaching and learning resources. The current study was to establish teachers' level of support in the use of teaching and learning resources for learners who are physically challenged in regular primary schools in Kisumu West Sub-County, Kenya.

\section{Statement of the Problem}

Despite the governments' continuing efforts over the years to solve the problem of dropout from schools among children who are physically challenged, this problem has persistently been on the increase. A policy (2018) that promote disability inclusion and mainstreaming across all education institution has been done in regular schools. However, schooling in Kisumu West Sub-County has not always met the strategic needs of the learners who are physically challenged like provision of adequate physical facilities and equipment to cater for their special needs like their counterparts in regular schools. It is also evident that in the year 2012 to 2016, 138 (31.9\%) learners who are physically challenged dropped out of school in Kisumu West Sub-County, 77 (28.4\%) learners who are physically challenged dropped out of school in Kisumu Central Sub-County and 31(21.8\%) learners who are physically challenged dropped out of school in Kisumu East Sub-County. A baseline survey done in 15 schools within the five zones in Kisumu West Sub-County (2017) revealed that number of learners who are physically challenged decreased as they move to higher classes. The reason for this high dropout in Kisumu West, Sub-County was yet to be investigated. This study therefore aimed at determining teachers' level of support to retain learners who are physically challenged so as to seek for other alternatives in which the dropout rates can be reduced. The key factors investigated were curriculum adaptation, teaching and learning resources, teaching and learning strategies and creation of awareness on learners who are physically challenged. Based on this background, this study intended to determine teachers' level of support to retain learners who are physically challenged in regular primary schools in Kisumu West Sub-County, Kenya.

\section{Purpose of the Study:}

The purpose of this study was to find out teachers` level of support in the use of teaching and learning resources of learners who are physically challenged in regular primary Schools in Kisumu West Sub County, Kenya.

\section{Study Objective:}

The objectives of the study was therefore to; 
(i) Establish teachers' level of support in the use of teaching and learning resources of learners who are physically challenged in regular primary Schools in Kisumu West Sub County, Kenya.

\section{Research Questions}

The study was guided by the following research question

(i) To what extent do teachers the use of teaching and learning resources of learners who are physically challenged y in regular primary schools in Kisumu West Sub- County, Kenya?

\section{Assumptions of the Study}

The study was based on the following assumptions:

(i) That learners who are physically challenged were in regular primary schools in Kisumu West Sub-County, Kenya.

(ii) Teachers were aware that they were supposed to provide support to learners who are physically challenged in regular primary schools.

(iii) That information obtained from the respondents was accurate and relevant.

\section{Scope of the Study}

The study was carried out in fifteen regular primary schools having large number of learners who are physically challenged in the sub-county with teachers teaching them.

\section{Limitations of the Study:}

The use of questionnaires might have produced information that was influenced by ceiling and floor effects, by the respondents either overstating or suppressing their responses to impress the researcher. This was assessed by the use of interview schedules.

\section{Significance of the Study:}

The outcome of the study may be significant to head teacher and teachers in identifying teachers level of support to retain learners who are physically challenged in regular schools. It may be useful to Ministry of Education, EARC officers and parents in ensuring equal educational opportunities for learners with Special Needs Education in regular primary schools. The knowledge generated by this study may therefore enable other Development in designing appropriate instructional goals for special needs education. Educational Assessment and Resource centers may benefit in their mission to identify, assess, intervene and properly place learners with special needs.

\section{Conceptual Framework:}

The conceptual framework outlines an illustration that the study employed in analyzing the teachers level of support to retain learners who are physically challenged in regular primary schools in Kisumu West Sub- County, Kenya 
Fig. 1. Conceptual framework showing interaction of teachers` level of support in the use of learning resources to retain learners who are physically challenged in regular primary schools

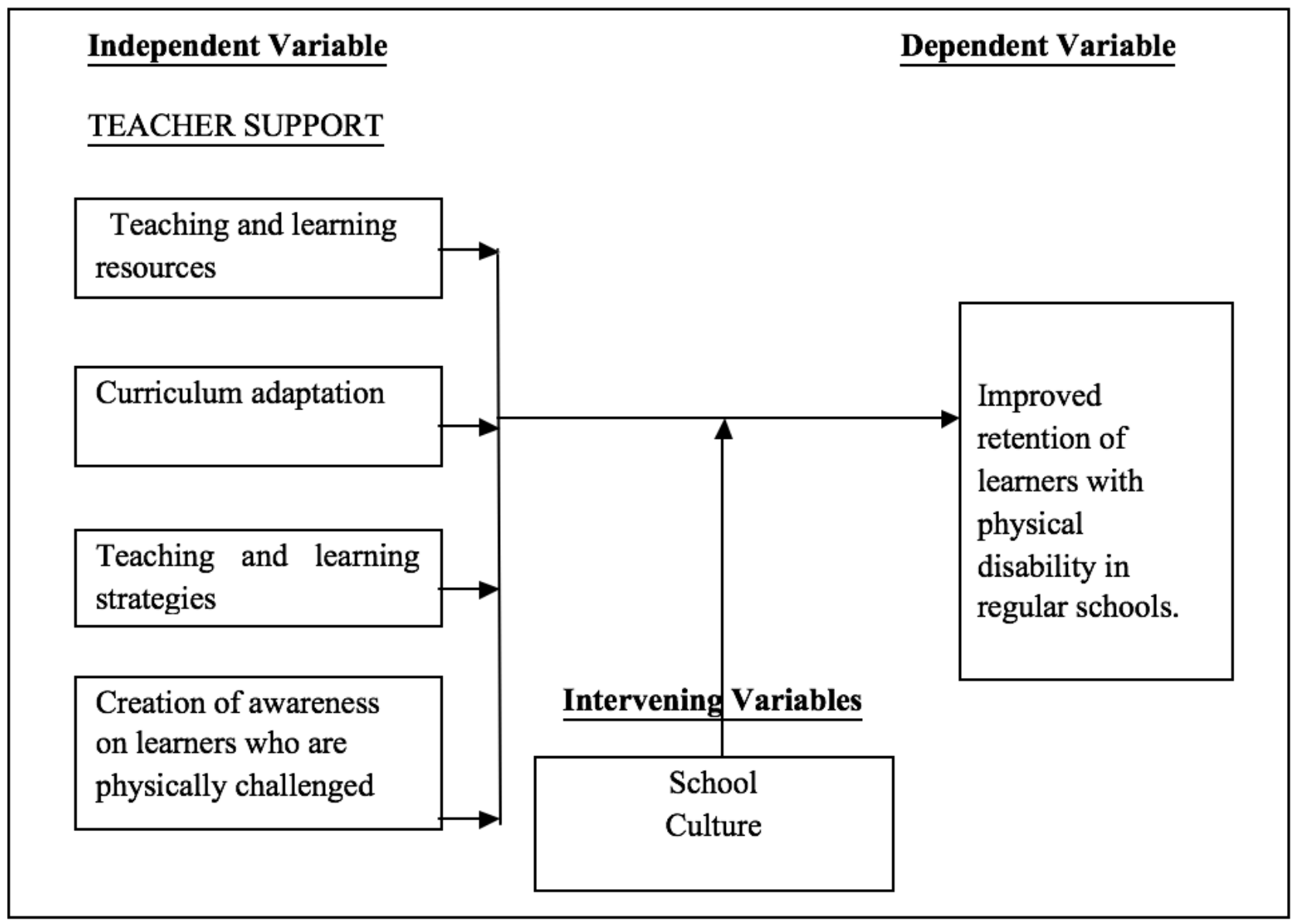

Source: Researcher's own adaptation

This study was based on the conceptual framework Figure 1.1 implies a significant relationship between the dependent and independent variables of the study. The independent variables are learning and teaching resources, curriculum adaptation, teaching and learning strategies and creation of awareness on learners who are physically challenged, If these factors are well manipulated and strategized by the teachers would lead to improved retention and quality education of learners who are physically challenged in regular primary schools.

Intervening variables in this study refers to school culture. Culture is viewed as a representation of process that a group of people share and cherish (Erickson, 1986). Consequently culture plays an important role in students` learning styles and understanding of meanings (Cush et al., 1992) in a given school or context as illustrated in Figure 1.1. These factors can directly affect retention and dropout of learners who are physically challenged either positively or negatively. This can further affect successful implementation of inclusive education in regular primary schools.

Inclusion of learners who are physically challenged in regular primary schools was the dependent variable. This was determined by successfully providing quality education and retaining learners who are physically challenged in schools. Usually there is only one dependent variable and it was the outcome variable the researcher attempted to predict (Kombo \& Tromp, 2009). 


\section{RESEARCH METHODOLOGY}

This chapter covers the research methodology used in the study as follows;

\section{Research Design}

The study adopted a descriptive survey design. Descriptive survey design was relevant for this study because it involves collection of data from a sample of a population in order to determine the current status of that population with respect to one or more variables (Mugenda \& Mugenda, 2008). It can provide information about the distribution of a wide range of peoples characteristics and of relationship between such characteristics (Creswell, 2009).The use of descriptive survey design in this study enabled the researcher to find out facts without manipulation of data, seeking opinion, describe, analyze and interpret teachers' level of support to retain learners who are physically challenged in regular schools.

\section{Area of Study}

The study was conducted in Kisumu West Sub-County in regular primary schools that enrolled learners who are physically challenged. This Sub-County is one of the seven sub-counties forming Kisumu County. Vihiga and Nandi County board it in the North, Kericho County to the East, Homabay County to the South, Winam Gulf and Siaya County to the West. It lies within Longitudes $34^{\circ} 34^{\circ}$ and $34^{\circ} 45^{\circ} \mathrm{E}$, and Latitudes $0^{0} 20^{\circ}$ and $0^{0} 45^{\circ} \mathrm{N}$. The total area of Kisumu WestSub-County is 358.7 square kilometers. It covers about 17.2 percent of the total area of Kisumu County which is 2,086 $\mathrm{Km}^{2}$. Kisumu West Sub-County was chosen because of high number of learners who are physically challenged who have dropped out of school after being placed in schools. The study involved 15 regular primary schools. There are 706 primary schools and about six thousand one hundred teachers. It is majorly inhabited by Luo Community whose major occupations are agriculture and fishing. They attach great importance to the better quality education to their children in order to increase earning in the modern sector. Education is seen as the only vehicle, of employment since the county has limited resources with poverty incidence at the rate of 45\% (Republic of Kenya, 2009).

\section{Study Population}

The study population constituted of 15 head teachers, 30 teachers, 90 learners who are physically challenged and 6 EARC coordinators. The total population was 141.Two teachers handling Maths and English or Kiswahili in learners' classes, per school were purposively selected from all the 15 regular primary schools in 5 Zones (Chulaimbo, Sianda, Ojolla, Nyahera and Otonglo) in Kisumu West Sub County, Kisumu. Teachers were preferred in this study because of being in direct contact with the learners and directly involved in the implementation of curriculum. Head teachers were also preferred due to their vital role to supervise, coordinate and plan for the curriculum implementation in the school while EARC coordinators gave advisory services. In the current study, 6 learners who are physically challenged in classes four, five and six were chosen from each of the 15 regular primary schools giving a total of 90 learners (Baseline Survey, 2016).

\section{Sample and Sampling Techniques}

Sampling is the process of selecting smaller portions of the larger population to be studied in order to draw conclusions from the sample to the population from which the sample was drawn (Orodho, 2009). Saturated sampling technique was used to select 13 head teachers, 4 EARC coordinators. Saturated sampling techniques is a non-probability sampling technique in which all the members of the target population are selected because they are few to make a sample out of them (Gall \& Borg, 2007). Purposive sampling technique was used to select 27 teachers teaching Mathematics and English or Kiswahili to learners who are physically challenged, 81 learners who are physically challenged were purposively selected among other learners in the sampled regular primary schools, in the five zones in Kisumu West sub-county. 
Purposive sampling is a non-probability sample that is selected based on characteristics of a population and objective of the study. Two head teachers, three teachers, two EARC coordinators and 9 learners were used for pilot study. This population was not part of the actual study (Palys, T. 2008). This is shown in Table 1.

Table: 1: Study Population and Sample Frame.

\begin{tabular}{lcccc}
\hline Category of respondents & Total Number & Pilot & Sample Size & Percentage \\
& & & & \\
\hline Head teachers & 15 & 2 & 13 & $87 \%$ \\
Teachers & 30 & 3 & 27 & $90 \%$ \\
EARC & 6 & 2 & 4 & $67 \%$ \\
Learners & 90 & 9 & 81 & $90 \%$ \\
Total & $\mathbf{1 4 1}$ & $\mathbf{1 6}$ & $\mathbf{1 2 5}$ & $\mathbf{8 9 \%}$ \\
\hline
\end{tabular}

Source: Researcher's field data

\section{Instruments of Data Collection}

The study used questionnaire, interview schedules and observation schedule as the main instruments of data collection. There were three sets of questionnaires for head teachers, teachers and learners who are physically challenged. Interview schedule was used to collect information from head teachers and EARC coordinators. Observation schedule was used to gather information regarding the availability and use of teaching/learning resources, and various strategies used by teachers to assist learners who are physically challenged.

\section{Head teachers Questionnaire (HTQ)}

Burke and Larry (2011) noted that questionnaires were commonly used to obtain important information about a population within a quick space of time. De Vaus (2002) defines a questionnaire as a highly structured data collection technique whereby each respondent is asked the same set of questions. The questionnaire was used to establish teachers' level of support to retain learners who are physically challenged. The questionnaires used consisted of both open-ended and closed-ended question items with five point likert scale format type of questions. Head teachers questionnaires had structured items addressing specific issues on the learning resources, curriculum adaptation, teaching strategies and creation of awareness that contribute to support in retaining learners who are physically challenged. The respondents were also asked to rate their responses on a five point rating scale (HTQ Appendix A).

\section{Head teachers Interview Schedule (HIS)}

Interview is a conversation whereby the researcher gets information from respondents by interacting with them face to face. It is a flexible tool in collecting data, enabling multisensory channels to be used; verbal, non-verbal, spoken and heard (Cohen, et al, 2007). This method was recommended in this study because it enabled the researcher to explore complex issues in support to retain learners who are physically challenged. The interview consisted with one section of 5 items with open-ended questions. The data collected was used to find out how the use of teaching and learning resources, curriculum adaptation, suitable methods of teaching and creation of awareness improved retention and reduced dropout of learners who are physically challenged in regular primary schools (Appendix).

\section{Teacher's Questionnaire (TQ)}

Questionnaires were administered to the class-teachers to seek for information on teachers' level of support to retain learners who are physically challenged. Questionnaire for the teachers had five parts which sought to solicit demographic information, teaching and learning resources, curriculum adaptation, suitable methods of teaching and creation of awareness on 
learners who are physically challenged in regular primary schools. The questionnaire consisted of closed-ended and open-ended questionnaire items with five point likert scale format type of questions. Closed-ended questions were included because they are easy to administer, easy to analyze and therefore economical in terms of time and money. The closed-ended questions used five- option Likert scale. The respondents were also asked to rate their responses on a five point rating scale (Appendix B).

\section{Learner`s Questionnaire (LQ)}

The item was administered to learners who are physically challenged. It was used to gather information on teaching and learning resources, strategies employed by regular schools in coping with peers in classroom, views on improving retention and reduce dropout. The questionnaire consisted of closed-ended and open-ended questionnaire items with five point likert scale format type of questions. (See Appendix C).

\section{Assessment and Resource Centre Coordinators' Interview Schedules (EARCIS).}

Interview is a conversation where the researcher asked the respondents questions intended to yield in-depth information on the theme of the study. It is an effective tool in collecting data that may be difficult to access when applying other research techniques such as questionnaire. In this study, EARC coordinators were asked to address matters on information regarding teaching and learning resources, teaching strategies and creation of awareness to members of the school. Probing was used by the researcher to get deeper information. A friendly relationship with prospective respondents prior to the actual interview was a prerequisite for obtaining maximum cooperation and accurate information. Interview schedules were flexible and yielded high response rate and offered opportunity to collect in-depth information (See Appendix D).

\section{Observation Schedule (OS)}

An observation checklist is used by the researcher to collect data about what defined behaviors and activities a researcher observes during data collection period (Gay et al, 2009). The researcher with the help of observation checklist, observed the availability and use of teaching and learning resources in the classrooms.

These included physical facilities in the school like, presence of level playground, learning resources, toilets, spacious classrooms, ramps, if they are adapted to the needs of learners who are physically challenged. Observation was also used in this study to collect information on various strategies used by the teachers to assist learners who are physically challenged. It involved observing a total of two lessons for Mathematics and English or Kiswahili subjects in randomly chosen classes where learners who are physically challenged were. The advantage of observation was that it blended well with other gathering instruments such as questionnaire and interviews (Creswell, 2009).

\section{Validity and Reliability of the Research Instruments}

Validity refers to the quality of data gathering instruments or procedure that enable instrument to measure what it is supposed to measure while, reliability is the degree of consistence that a research instrument demonstrates (Creswell, 2009).

\section{Validity of the Research Instruments}

Validity refers to the degree to which results obtained from analysis of data actually represent the phenomenon under study (Mugenda and Mugenda (2003). In this study, face and content validity were used. Face validity is a qualitative means of a ascertaining whether a measure on the face of it appears to reflect the content of a concept (Creswell, 2009). Content validity is a 
qualitative means of ensuring that a measure includes an adequate and representative set of items to cover a concept (Drost, 2011). In the current study, the determination of face and content validity of the research instruments confirmed the accuracy and connection among the questions asked and variables measured. Face and content validity are ensured by obtaining subjective judgments by the experts of the concerned field (Creswell, 2003; Drost, 2011).

To verify the validity of the instrument used, the research instruments were presented to experts from Special Needs Education and Rehabilitation, who were conversant with topic of study to ascertain. The experts read and judged the instrument independently and made recommendations on each part testing each objective. Later, the researcher made corrections based on recommendations before the instruments were used in the field.

\section{Reliability of the Research Instruments}

The reliability is a measure of the degree to which a research instrument yields consistent of data after repeated trials (Mugenda \& Mugenda, 2003; Orodho, 2004). Reliability of the research instruments was established using test-retest method through a pilot study. For pilot study, ten percent of the study population which was not part of the actual study was selected; where 13 head teachers, 27 teachers, 81 learners who are physically challenged and 2 EARC coordinators were involved. The study used three instruments; head teachers, teachers and learners questionnaire, head teachers' and EARC coordinators interview schedule and observation checklist. Tests were administered to the respondents by the researcher herself for the first time. Later, the tests were re-administered to the respondents after two weeks. Means scores from the test were then correlated using Pearson product moment correlation coefficient (Formula used is shown below ). Reliability coefficient for; the head teachers' questionnaire was 0.8 , teachers' questionnaire was 0.9 and questionnaire for learners who are physically challenged was 0.7 . This was above the acceptable value of 0.7 and above (Mugenda \& Mugenda, 2003; Orodho, 2004) which confirmed that the tests were reliable. The data collected through qualitative technique was counter checked thematically to ascertain consistency. Any inadequacies, inconsistencies and weaknesses of the research instruments identified during the pilot study were corrected.

\section{Data Collection Procedures}

The researcher obtained a research permit to visit regular primary schools in Kisumu West Sub-County from the Maseno University Ethics and Research Committee (MUERC) through Maseno University School of Graduate Studies (SGS). The researcher then paid courtesy calls at the County Director of Education Office, Sub-county Director Education Office and the head teachers' offices in the 13 regular primary schools. Permission was sought from the head teachers and researcher met the participants for good public relations and to inform them that ethical principles has to be upheld throughout the study. The researcher later on visited the schools and administered the questionnaires personally to both head teachers, teachers and learners who are physically challenged (Bobbie, 2008).Help was sought from teachers teaching English or Mathematics in the classes where learners who are physically challenged were. Interview schedules were administered to the head teachers and EARCs coordinators by the researcher herself. The questionnaires were collected immediately the research participants completed filling them. This ensured high return rate of the questionnaires.

\section{DATA ANALYSIS}

Data analysis is the process of systematically searching and arranging notes, data and other materials obtained from the field with an aim of increasing understanding and enable one to present them to others (Orodho, 2009). The research produced data that require both quantitative and qualitative analysis. Quantitative data collected from the questionnaires was 
coded manually, entered into the Statistical Package for Social Sciences (SPSS) data sheet before analyzing it using SPSS - 11.5 version. Analysis of data was done as per the objectives. In order to analyze teachers' level of support in the use of teaching and learning resources required by learners who are physically challenged, frequency tables were used to cross check totals for each variable expressing a particular aspect such as learning materials and physical facilities. Relationship between independent and dependent variables was found using correlations. To establish teachers' level of support in curriculum adaptation, frequency tables were used. Objective three employed the means, frequency counts and percentages to find out teachers' level of support in teaching and learning strategies. For objective four, frequency tables were used to determined teachers' level of support in creation of awareness. Key findings were explained, summarized and conclusions made. A narrative report was written and enriched with verbatim from respondents and included in the report. Qualitative data collected from interview schedules and observation checklist were organized, put in various categories and reported in an ongoing process as themes and sub-themes emerged.

In coding and interpretation of the questionnaires from head teachers, teachers and learners, the positively stated items on the five point likert scales were coded with each of the five points rating scale being given: Strongly Agree (SA) - 5 points, Agree (A)- 4 points, Fair Agree( FA)- 3 points, Disagree (D) - 2 points, Strongly Disagree (SD) - 1 point.

For those statements that were negative, the scoring procedure was reversed. Mean score for each item were then worked out. In the interpretation of scores, a mean score of above 5.0 3.01 indicated most respondent agreed with teachers level of support to retain learners; a mean score of 3.0 indicated that respondents were neutral while a mean score of blow $2.99-1$ implied negative impact on improving retention of learners who are physically challenged in regular primary schools (Kothari, 2008; Best and Kahn, 2006).

\section{ETHICAL CONSIDERATIONS}

The researcher sought clearance from Maseno University School of Graduate Studies (SGS). She then obtained a permit from Maseno University Ethics and Research Committee (MUERC) to be able to collect data in the targeted regular primary schools in Kisumu West Sub-County. The researcher ensured and assured the respondents that their responses would be treated in strict confidentiality (Kombo and Tromp, 2009). Confidentiality is a key ethical issue in research, the research ensured utmost confidentiality of the respondents and school names by using codes instead of the real names, the data collected was used for research only, the researcher obtained consent from the parents of pupils using consent letter. This was because most learners in primary schools were below eighteen years (minors). Thus, it was important for the researcher to seek permission from the parents. See Appendix E

\section{RESULTS AND DISCUSSION \\ Teachers' level of Support in Teaching and Learning Resources}

The first objective of this study was to establish teachers' level of support in the use of teaching and learning resources of learners who are physically challenged in regular primary schools in Kisumu West Sub-county. The data was collected using a questionnaire for respondents which addressed the following; Teaching and learning resources required, resources available and used in class by the teacher, physical facilities available and modified. They were expected to select from a rating scale ranging from "Strongly Disagree" (1) to "Strongly agree" (5). It was coded and analyzed using frequency, percentages and means. The results were presented in tables starting with table2. 
Table 2: Teaching and Learning Resources Required for Learners Who are Physically Challenged in Regular schools Teachers $=27$

\begin{tabular}{lcccccc}
\hline Resources required & $\begin{array}{c}\text { SA } \\
\mathbf{f ( \% )}\end{array}$ & $\begin{array}{c}\text { A } \\
\mathbf{f ( \% )}\end{array}$ & $\begin{array}{c}\text { FA } \\
\mathbf{f ( \% )}\end{array}$ & $\begin{array}{c}\text { D } \\
\mathbf{f ( 0 \%}\end{array}$ & $\begin{array}{c}\text { SD } \\
\mathbf{f ( \% )}\end{array}$ & Mean \\
\hline Blackboard & $22(81.5)$ & $2(7.4)$ & $1(3.7)$ & $2(7.4)$ & $0(00)$ & $\mathbf{4 . 6 2}$ \\
Text and Exercise bks & $14(51.9)$ & $2(7.4)$ & $3(11.1)$ & $5(18.5)$ & $3(11.1)$ & $\mathbf{3 . 7 0}$ \\
Charts & $11(40.7)$ & $3(11.1)$ & $1(3.7)$ & $8(29.6)$ & $4(14.8)$ & $\mathbf{3 . 3 3}$ \\
Modified pencils/pens & $0(00)$ & $2(7.4)$ & $0(00)$ & $0(00)$ & $25(92.5)$ & $\mathbf{1 . 2 2}$ \\
Book hold & $0(00)$ & $1(3.7)$ & $0(00)$ & $0(00)$ & $26(96.2)$ & $\mathbf{1 . 1 1}$ \\
Head pointer & $0(00)$ & $1(3.7)$ & $0(00)$ & $0(00)$ & $26(96.2)$ & $\mathbf{1 . 1 1}$
\end{tabular}

Key: of Strongly Agree (SA)-5, Agree (A)-4, Fairly Agree (FA)-3, Disagree (D)-2, Strongly Disagree (SD)-1, f- Frequency count, \%- Percentage

Table 2 shows some of the teaching and learning resources required for learners who are physically challenged. According to the respondents. The teachers responses were as follows; out of the number of teachers sampled 22 ( 81.5\%) strongly agreed that blackboards were in regular schools, $2(7.4 \%)$ agreed that they were available, $1(3.7 \%)$ fairly agreed and $2(7.4 \%)$ disagreed. This had a mean score of 4.62 which meant that blackboards were the most required among the resources. As for the text and exercise books, 14 (51.9\%) of teachers strongly agreed that they were there, $2(7.4 \%)$ agreed that they were available, $3(11.1 \%)$ fairly agreed and $5(18.5 \%)$ disagreed while $3(11.1 \%)$ strongly disagreed. It had a mean score of 3.70 thus making it the second most required resource. The charts were rated as follows $11(40.7 \%)$ of teachers strongly agreed, 3 (11.1\%) agreed and $1(3.7 \%)$ fairly agreed that they were available, while $8(29.6 \%)$ of teachers disagreed, $4(14.8 \%)$ strongly disagreed that they were available. It was rated third with a mean score of 3.33. As for modified pencils/pens $2(7.4 \%)$ agreed that they were available, 25(92.5\%) strongly disagreed that they were available with a mean score of 1.22 . Book holder and head pointer $1(3.7 \%)$ agreed they were available, while $26(96.2 \%)$ with a mean of 1.11 strongly disagreed that they were available. According to this study, the most available resources were blackboard 22 (81.5\%), text and exercise books 14 $(51.9 \%)$ and charts $11(40.7 \%)$, the least available resources were modified pens $2(7.4 \%)$, head pointer $1(3.7 \%)$, book hold $1(3.7 \%)$. The findings revealed that regular primary schools did not have the most resources required by learners who are physically challenged. This differed with Moodley (2002) who noted that institutions must ensure that teaching and learning resources are made available and used by all the learners with special needs.

Table 3: Resources Available and Used in Class by the Teacher (Learners, $\mathbf{n}=\mathbf{8 1}$ )

\begin{tabular}{lcccccc}
\hline Resources & SA & A & FA & D & AD & Mean Score \\
& $\mathbf{f ( \% )}$ & $\mathbf{f ( \% )}$ & $\mathbf{f ( \% )}$ & $\mathbf{f ( \% )}$ & $\mathbf{f ( \% )}$ & \\
\hline $\begin{array}{l}\text { Blackboard } \\
\text { Text and }\end{array}$ & $70(86.4)$ & $0(00)$ & $0(00)$ & $11(13.6)$ & $0(00)$ & $\mathbf{4 . 5 9}$ \\
$\begin{array}{l}\text { Exercise books } \\
\text { Charts }\end{array}$ & $25(37.0)$ & $2(2.5)$ & $3(3.7)$ & $30(37.0)$ & $0(00)$ & $\mathbf{3 . 7 4}$ \\
$\begin{array}{l}\text { Modified } \\
\text { pencils/pens }\end{array}$ & $0(00)$ & $0(2.5)$ & $1(1.2)$ & $48(59.3)$ & $5(6.2)$ & $\mathbf{2 . 9 2}$ \\
Head pointer & $0(00)$ & $0(00)$ & $0(00)$ & $3(3.7)$ & $78(96.3)$ & $\mathbf{1 . 0 4}$ \\
Book hold & $0(00)$ & $0(00)$ & $0(00)$ & $0(00)$ & $81(100)$ & $\mathbf{1 . 0 0}$ \\
\hline
\end{tabular}

Key: SA- Strongly Agree, A- Agree, FA- Fairly Agree, D- Disagree, SD- Strongly Disagree, fFrequency count, \%- Percentage 
Learners' response on resources available and used in class was analyzed using a five Likert scale: Strongly Agree 5, Agree -4, Fairly Agree - 3, Disagree - 2, Strongly Disagree - 1. The results were presented in Table 3.

The findings in table 3 indicates that $70(86.4 \%)$ of learners agreed that blackboard was available resource and used in class by the teachers and 11(13.6\%) of learners disagreed with a mean of 4.59. As for text and exercise books, 46 (37.0\%) learners strongly agreed, 2 (2.5\%) of learners agreed, $3(3.7 \%)$ of learners fairly agreed and $30(37.0 \%)$ of learners disagreed. This make it second resource available and used by teachers with mean of 3.74 . Twenty five $25(37.0 \%)$ of learners strongly agreed that charts were available and used in class, $2(2.5 \%)$ agreed, 1(1.2\%) fairly agreed, $48(59.3 \%)$ of learners disagreed and $5(6.2 \%)$ of learners strongly disagreed. It was rated third with a mean of 2.92 . Book hold $5(6.2 \%)$ of learners disagreed and $76(93.8 \%)$ strongly disagreed with a mean of 1.06. Modified pencils/pens $3(3.7 \%)$ of learners disagreed and $78(96.3 \%)$ strongly disagreed with a mean of 1.04 while $81(100 \%)$ of learners strongly disagreed that head pointer was available with a mean of 1.00 . The findings revealed that the least available resources in class included head pointer $(M=1.00)$, modified pencils/pens $(M=1.0 X 4)$ and book hold $(M=1.06)$. The findings do not concur with the findings of Moodley (2002) who noted that institutions must ensure that teaching and learning resources are used as well as made available to all the learners with special needs according to their needs.

\section{Physical facilities Modified to Accommodate Learners}

Table 4: Physical facilities Modified to Accommodate Learners who are Physically Challenged in your Schools (Teachers $=27$ )

\begin{tabular}{lcccccc}
\hline Category & SA & $\mathbf{A}$ & $\mathbf{F A}$ & $\mathbf{D}$ & $\mathbf{S D}$ & Mean \\
& $\mathbf{f ( \% )}$ & $\mathbf{F ~ ( \% )}$ & $\mathbf{f ( \% )}$ & $\mathbf{f ( \% )}$ & $\mathbf{f ~ ( \% )}$ & \\
\hline Ramps & $10(37.0)$ & $0(00)$ & $0(00)$ & $12(44.4)$ & $5(18.5)$ & $\mathbf{2 . 9 2}$ \\
Adapted toilets & $8(29.6)$ & $0(00)$ & $0(00)$ & $0(00)$ & $197(0.4)$ & $\mathbf{2 . 1 9}$ \\
$\begin{array}{l}\text { Adapted chairs \& desks } \\
\text { Accessible, spacious }\end{array}$ & $8(29.6)$ & $0(00)$ & $0(00)$ & $0(00)$ & $19(70.4)$ & $\mathbf{2 . 1 9}$ \\
classroom & $14(51.9)$ & $0(00)$ & $0(00)$ & $13(48.1)$ & $0(00)$ & $\mathbf{3 . 5 5}$ \\
Level playgrounds & $12(44.4)$ & $0(00)$ & $0(00)$ & $12(44.4)$ & $3(11.1)$ & $\mathbf{3 . 2 2}$ \\
\hline
\end{tabular}

Key f- Frequency count, \%- Percentage, M-Mean

Teacher's response on modified physical facilities to accommodate learners was analyzed using a five Likert scale: Strongly Agree 5, Agree -4, Fairly Agree - 3, Disagree - 2, Strongly Disagree -1 . The results were presented in Table 4 .

According to table 4, 14 (51.9\%) of the teachers strongly agreed that accessible, spacious classrooms was modified and $13(48.1 \%)$ of the teachers disagreed with a mean of 3.55. As for leveled playground, 12(44.4\%) of teachers strongly agreed, 12 (44.4\%) of the teachers disagreed and $3(11.1 \%)$ strongly disagreed with a mean of 3.22 . This was followed by a total of $10(37.0 \%)$ teachers who indicated that they strongly agree ramps were available, $12(44.4 \%)$ of the teachers disagreed and 5(18.5\%) teachers indicated disagree with a mean of 2.92. Eight $(29.6 \%)$ of the teachers strongly agreed that adapted toilets were available and $19(70.4 \%)$ of the teachers strongly disagreed that adapted toilets were available while $8(29.6 \%)$ of the teachers strongly agreed that adapted chairs and desks were available and $19(70.4 \%)$ of the teachers strongly disagreed that adapted chairs and desks were available in their schools with a mean of 2.19. The study reported that accessible, spacious classroom 14 (51.9\%) was available and adapted, followed by level playground 12 (44.4.0\%). The least available inadequate adapted physical facilities were adapted toilets and adapted chairs and desks. 
To confirm teachers responses, 11 (84.6\%) of the head teachers of the regular primary schools sampled interviewed reported that their schools had no enough adapted resources and only 3 (23.1\%) reported they had. Therefore, this might have led to a large number of learners who are physically challenged to lose interest and dropout of school. The findings concur with Thuo (2009) who said that majority of schools were in dire need for relevant teaching and learning resources to enhance retention in inclusive education.

The observation made (Table 5.) in the regular primary schools where learners who are physically challenged learn confirmed that some teaching resources were in adequate and not adapted. This is supported by Kochung Report (2003) which found that out most schools were operating with barely basic learning resource.

These study findings noted that the most modified physical facilities available in regular schools were accessible, spacious classrooms $(\mathrm{M}=3.55)$, followed by level playgrounds $(\mathrm{M}=3.22)$. The least available modified physical facilities were adapted toilets $(\mathrm{M}=2.19)$ and adapted chairs and desks ( $M=2.19)$ that were most needed by learners who are physically challenged. The fact that the majority schools in Kisumu West Sub-County were poorly equipped was a contributing factor to dropout and poor retention of learners who are physically challenged in regular schools. Teachers could not discharge their duty in supporting learners effectively. The findings concurred with Daveta (2009) finding who stressed that buildings and classroom layout should be structured to accommodate learners with disabilities. According to UNESCO (2004), the learners must be provided with adapted learning materials in formats that meet their individual needs and reduce the dropout.

Table 5: Available Teaching and Learning Resources Observed in Schools $\quad(n=13)$

\begin{tabular}{lcc}
\hline Teaching/Learning & $\begin{array}{c}\text { Frequency } \\
\text { Resources }\end{array}$ & $\begin{array}{c}\text { Percentage } \\
\text { N }\end{array}$ \\
\hline Blackboard & 13 & 100.00 \\
Text and Exercise bks & 13 & 100.00 \\
Charts & 6 & 46.2 \\
Modified pencils/pens & 0 & 00 \\
Head pointer & 0 & 00 \\
Book hold & 0 & 00 \\
Physical Facilities & 5 & \\
Ramps & 4 & 39.0 \\
Adapted chairs/desks & 3 & 31.0 \\
Adapted toilets & 0 & 23.1 \\
Lowered door handles & 11 & 00 \\
Spacious Classrooms & 9 & 85.0 \\
Leveled playground & & 69.2 \\
\hline
\end{tabular}

Key: N = Number of schools

The observation made in the visited schools is summarized in Table 5 .

The table shows that out of 13 schools visited, 13(100.0\%) had blackboard and text /exercise books, 6 (46.2\%) had charts. None of the schools visited had modified pencils/pens, head pointer and book holder. The physical facilities observed and the results shows that $11(85 \%)$ schools had spacious classroom, $9(692 \%)$ had leveled playground, followed by $5(39.0 \%)$ schools with ramps. The schools having adapted chairs/desks were only $4(31.1 \%)$ while $3(23.1 \%)$ schools had adapted toilets. None of the schools had lowered door handles. The result of the study showed that some relevant teaching resources were in adequate and not adapted in regular primary schools in Kisumu West Sub-County. This is in support of Kuching Report (2003) which found out most schools were operating with barely basic learning aids. 


\section{Summary of the findings}

\section{SUMMARY, CONCLUSION AND RECOMMENDATIONS}

The findings of this study are summarized in relation to the research objectives.

\section{Teaching and Learning Resources for Learners who are Physically Challenged}

Most teachers responded on teaching learning resources required; blackboard very adequate in regular schools $(M=4.62)$, text and exercise books $(M=3.77)$, Charts $(3.33)$, book holder, head pointer and modified pencils/pens not available at all (1.00). The learners indicated in Table 6, that the most adapted resources required were not available.

Both the respondents revealed that the most modified physical facilities available in regular schools were accessible, spacious classrooms 11 (84.6\%), 14 (51.9\%), followed by level playgrounds 7 (53.8\%), $12(44.4 \%)$ and least modified physical facilities available were adapted toilets 4 (31.0\%), 5 (18.5\%), adapted chairs and desks 3 (23.1\%), 4 (14.8\%) and ramps 5 (38.5\%), 7 (25.9\%).

The findings on availability of the teaching/learning materials and equipment, majority of the respondents reported that blackboard, text/exercise books, charts, spacious classroom, level playground, were available in most of the schools. They also reported that book holder, head pointer, modified pencils, adapted chairs, adapted toilets and rumps were inadequate in the schools. Observation by the researcher confirmed the unavailability of the resources and also EARCs coordinators. In this regard, provision of adapted teaching/learning resources could enhance teachers high level of support leading to improved retention.

\section{Conclusion}

\section{Teaching and Learning Resources for Learners With Physical Disability}

The study revealed that most of the regular primary schools did not have teaching learning resources such as book holder, modified pens and head pointers required for learners with physical disability but those who had, none had enough for all learners as indicated by the respondents and EARC coordinators.

\section{Recommendations}

i) Based on the findings that teaching and learning resources required for learners who are physically challenged were not available in most inclusive schools and those who had, did not have enough for all learners, this study recommended that the government through ministry of education should ensure adequate supply of teaching and learning materials, this will encourage teachers in providing support to learners with disabilities in regular primary schools.

\section{Suggestions for Further Research}

1. Further study may be carried out in relation to the dropout of learners with special needs education in regular primary schools.

\section{References}

Abbott, L. (2006). Northern Ireland head teachers' perceptions of inclusion. International Journal of Inclusive Education, 10 (6), 627-643.

Adeyemo, D. A. (2005). Parental Involvement Interest in Schooling and School Environment as predictors of Academic Self-efficacy among fresh Secondary School Student in Oyo State, Nigeria. Electronic Journal of Research in Educational Psychology, 5-3 (1) 163.

Agbenyega, J., \& Deku, P. (2011). Building new identities in teacher preparation for inclusive education in Ghana. Current Issues in Education, 14(1), 1-36. 
Ainscow, M., Booth, T., \& Dyson, A. (2006). Improving schools, developing inclusion. Abingdon: Routledge

Ali, M. M., Mustapha, R. and Jelas, Z. M. (2006). An empirical study on teachers' perceptions towards inclusive education in Malaysia. International Journal of Special Education.

Amuto, S. (2002). Standard of Competence in Braille Literacy Skills in teacher Preparation Programmes; Journal of Visual Impairments and Blindness.

Andrews, L. (2002) Preparing general education pre-service teachers for inclunsion: Web-enhanced case-based instruction, Journal of Special Education Technology, 17, 27-35.

Atkinson, D. (2004) Theorising how student teachers from their identies in initial education. British Educational Research Journal, 30 (3), 379-394.

Avramidis, E. \& Norwich, B. (2002). European Journal of Special Needs Education, Vol.17 No. 2 Teachers Attitudes Towards Integration/Inclusion.

Avrimidis, E., Bayliss, P., \& R. (2000). A survey into mainstream teachers' attitudes towards the inclusion of children with special educational needs in the ordinary school in one Local education authority. Educational Psychology, 20(2), pp191-212

Berry, A.W. R. (2011) 'Voices of experience: general education teachers on teaching Students with disabilities', International Journal of Inclusive Education, Vol.15 (6), pp627-648.

Best, W. J. \& Khan, V. J. (2006). Research in Education (10"th Ed.): New Delhi: Prentice - Halll.

Booth, T., Ainscow, M., \& Kingston, D. (2006). Index for inclusion: Developing play, learning and participation in early years and childcare. Bristol, UK: Centre for Studies on Inclusive Education.

Brandon, D.P (2006). Botswana's family and consumer sciences teachers' attitude towards the inclusion of students with physical disabilities. Journal of Family and Consumer Sciences Education, 24(1), 37-49.

Burke, J., \& Larry, C. (2011). Educational research: quantitative, qualitative and mixed approaches. Thousand Oaks, CA: Sage

Caroll, A., Forlin, C., \& Jobling, A. (2003). The impact of teacher training in special education on the attitudes of Australian pre-service general educators towards people with disabilities. Teacher Education Quarterly, 30(3), pp 65-73.

Chalmers, L. (2006). Modifying curriculum for the Special Needs Student in Regular Classroom.

Chhabra, S., Srivastava, R. \& Srivastava, I (2010). Inclusive Education in Botswana: The Perceptions of School Teachers, Journal of Disability Policy Studies, 2 (4), 219-228.

Charles, S. (2011) Basic school teachers' attitudes towards inclusive education in Ghana. (A Master's Thesis in Education) University of Jyväskylä - Finland.

Cohen, L. Manion, L. \& Morrison, K.L. (2007). Research Methods in Education. The Qualitative Paradigm. University of Sheffield (n.d). Retrieved In July 2016 from New York: Routledge. http://www.computing.dcu.ie/\%7Ehruskin/RM2.htm

Cologon, K. (2010). 'Inclusion is really what teaching is'. ARNEC Connections, 3, 45-48.

Cook, B. (2002). Inclusive attitudes, strengths, and weaknesses of pre-service general sion educators enrolled in a curriculum infusion teacher preparation program. Teacher Education and Special Education, 25 (3), 262 - 277.

Cooper, H., Robinson,J.C., \& Pattal(2006)Dukestudy:Homework help students succeed in school. http://www.dukenews.duke.edu/2006/03/homework.

Creswell, J. W. (2009) Research Design: Qualitative, Quantitative and Mixed Methods Approaches Los Angels: SAGE.

Department of Education and Science (2007). Special Educational Needs: A Continuum of Support. Guidelines for Teachers. Dublin: Stationery Office

DePoy, E., \& Gilson, S. (2004). Rethinking disability: Principles for professional and social change. Pacific Grove, CA: Brooks-Cole.

Dietze, T. (2011) 'Sonderpädagogische Förderung in Zahlen.' Zeitschrift für Inklusion, 2, pp. 1-21. Disability Rights Commission (DRC) (2001).

Edwards, A. and Protheroe, L. and Hartley, D. (2009) Re-thinking teacher education: Collaborative responses to uncertainty. London 
Obara, D. A., \& Were, C. M. (2020). Teachers` level of support in the use of teaching and learning resources of learners who are physically challenged in regular primary Schools in Kisumu West Sub County, Kenya. Advances in Social Sciences Research Journal, 7(3) 92-112.

Evans, J., and Lunt, I. (2002). Inclusive education: Are there limits? European Journal of Special Needs Education, 17 (1), 1-14.

EFA Forum (2001).Country Reports: Kenya, Dakar, Senegal. Retrieved from http://www.unesco.org

Erickson, F. (1986). Qualitative Methods in Research on Teaching in M. Wittrock (Ed), Handbook of Research on Teaching ( $3^{\text {rd }}$ Ed. pp 119 - 161). New York: MacMilan

Ertmer, L. (2002). Implications of Mainstreaming Learners with Hearing Impairement. Australian Journal of Psychology.

Florian, L. (2009) 'Learning without Limits' an inclusive practice, Paper presented as the Learning without Limits seminar, June 2008, University of Cambridge.

Forlin, C., Loreman, T., Sharma, U. and Earle, C. (2009). Demographic differences in changing preservice teachers' attitudes, sentiments and concerns about inclusive education. International Journal of Inclusive Education, 13 (2), 195-2009.

Forlin, Chambers. (2010). 'Developing and Implementing Quality Inclusive Education in Hongkong: Implications for Teacher Education. International Journal of Special Education.

Gachathi Report (1976). The National Committee on Educational Objectives and Policies (NCEOP) Nairobi: Government printer.

Gall, O. Borg, R. (1996).Education Research. An introduction. New York, Longman.

Gaotlohoogwe, B. (2001). Inclusive education: An investigation of the support system for pupils with special educational needs in Botswana. Unpublished Masters Dissertation, University of Manchester.

Gay, L. R and Airsian, P. (2009). Educational Research Competencies for Analysis and Applications 9th Ed. London: Pearson Education Limited.

Gay, L., Mills, G., \& Airsian, P. (2011). Educational research (8th ed.). Upper Saddle River, NJ: Pearson

Giangreco, M.R., Cloninger, C.J. \& Iverson, V.S. (1998) Choosing outcomes and accommodations for children: a guide to educational planning for students with disabilities (2nd edition).

GPE. Results for Learning Report 2014/15: Basic Education At Risk.

Heacox, D. (2002). Differentiating instruction in the regular classroom: How to reach and teach all learners, Grades 3-12. Free Spirit Publishing.

Hue, M. (2012). Inclusion practices with Special Educational Needs in a Hong Kong secondary school: teacher's narratives from a school guidance perspective. British Journal of Guidance \& Counseling.

Jerlinder, K., Danermark, B., \& Gill, P. (2010). Swedish primary-school teachers' attitudes to Inclusion-The case of PE and pupils with physical disabilities. European Journal of Special Needs Education, 25, 45-57.

Jingrong, L. (2004). High Dropout Rate in Rural Schools.

Johnson, G. and Howell, A. (2009). Change in pre-service teacher attitudes toward contemporary issues in education. International Journal of Special Education, 24 (2), 35-41.

Kauffman, J.M. (2004). Characteristics of Emotional and Behavioral Disorders of Children and Youth. Upper Saddle River NJ: Merril and Prentice Hall.

Karande W.R. (2014). School based factors influencing participation of physically challenged learners in Kiambu municipality, Kenya. Unpublished MED project University of Nairobi.

Kenya Institute of Special Education (2007). Guidelines to Inclusive Education Nairobi: KISE.

Kenya National Commission on Human Rights (2007). Objects of Pity or Individuals with Rights: The Right to Education for Children with Disabilities. Nairobi: Longman publisher.

Klemm, K. (2013) Inklusion in Deutschland - eine bildungspolitische Analyse, Gütersloh. Gütersloh: Bertelsmann

Kochung, E. (2003) Ministry of Education Science and Technology, 'Report of the Task Force on Special Needs Education Appraisal Exercise', Nairobi, Kenya

Koech D. (1999): Totally Integrating Quality Education and Training, Report. Nairobi.

Kombo, D. K. \& Tromp, D.L.A. (2006). Proposal and thesis writing. Makuyu: Don Bosco. 
Kombo, D. K. \& Tromp, D.L.A. (2009). Proposal and thesis writing: An introduction. Pauline's Publication Africa. Nairobi, Kenya.

Kosomo, D. (2012). "Psychological Assessment of Visual Impaired Children in Integrated and Special Schools". Journal of Visual Impairment and Blindness, retrieved on 6/8/2016.

Kothari, C.R. (20008). Research Methodology: Methods and Techniques. ( $2^{\text {nd }}$ Ed.). New Delhi: New Age International (P) Ltd, Publishers.

Kozleski,E. A., Artiles, A., Fletcher, T., \& Engelbrecht, P. (2007). Understanding the dialectics of the local and the global in education for all: A comparative study. International Journal of Educational Policy, Research and Practice, $8(1), 19-34$.

Kiyuni, B.A., \& Mangope, B. (2011). Student teacher's attitudes and concerns about inclusive education in Ghana and Botswana. International Journal of Whole Schooling.

Kyle, W. (2009). Inclusive Education for Hearing Impaired. Education Core Studies Journal.

Lakhan, S. M. (2006). Towards Inclusive Education in Developing Country context: Teachers Opinions about How They Can Support Children with Special Needs Who Are Already Present in Mainstream School. The Aga Khan University: Nairobi.

Landrum, J. L. and Mcduffie, A.K. (2010): Learning Styles in the Age of Differentiated Instruction, Exceptionality: A Special Education Journal Vol 18 (1) PP 6-17.

Leornard Cheshire Disability (2002). Oriang Cheshire Inclusive Education: Baseline Survey. Kisumu: Lake Publishers \& Enterprise Limited.

Learner, J. (2006). Learning Disabilities and Related Disorders: Characteristics and Teaching Strategies. Houghton: Mattlin Campany.

Leornard Cheshire Disability (2002). Oriang Cheshire Inclusive Education: Baseline Survey. Kisumu: Lake Publishers \& Enterprise Limited.

Leung, C. H., \& Mak, K. Y. (2010). Training, understanding, and the attitudes of primary school teachers regarding inclusive education in Hong Kong. International Journal of Inclusive Education, 14(8), 829-842

Lindsay, G. (2007). Inclusive education: a critical perspective. British Journal of Special Education.

Lindsay, S \& McPherson, A. C. (2011). Strategies for Improving Disability Awareness and Social Inclusion of Children and Young People with Celebral Palsay. Child: Care, Health and Development, 35 (8), 809-816.

Loreman, T., Sharma, U., Forlin, C. \& Earle, C. (2005) Pre-service teachers` attitudes and concerns regarding inclusive education, in: Proceedings of the International Special Education Conference (ISEC) 2005, Glasgow.

Maina, E.N., (2009). Unpublished Master's Thesis Presentation on Factors Influencing Performance of Deaf Students in Mathematics in Kenya Certificate of Secondary Education. Maseno University, Kenya

Margazine: Daily Nation, 22 ${ }^{\text {nd }}$ October, 2015)

Mastropieri, M. and Scruggs, T. (2004). The inclusive classroom: strategies for effective instruction. New Jersey: prentice-Hall, Inc.

Mc Carthy, D.L. (2007). Investment for development and social change. McGraw Hill: New York.

Meijer, C., Soriano, V., and Watkins, A. (2007): "Inclusive education across Europe: Reflections upon 10 years of work from the European Agency for Development in Special Needs Education" Childhood Education, vol. 83, no. 6, pp 361-365.

Ministry of Education, Science and Technology (MoEST, 2003) 'A report of the Taskforce on Special Needs Education - Appraisal Exercise, Kochun`g Report, Nairobi, Government Printers.

Ministry of Education (2009): Education Statistics department Report, Nairobi.

Miller, D. (2003). An introduction to Jamaican culture to rehabilitation service provider. In J. .Stone, ed., Culture and disability; providing culturally competent services. London

Mittler, P. (2002). International experience in including children with disabilities in ordinary schools. http//www.eenet.org.uk/theory active - internet-exp.shtml.

MOE. (2010). Bangladesh national education policy 2010. (Publication No. SK/SHA: 4/cell: 2/2004/121). Dhaka, Bangladesh: Government Printing Office 
Obara, D. A., \& Were, C. M. (2020). Teachers` level of support in the use of teaching and learning resources of learners who are physically challenged in regular primary Schools in Kisumu West Sub County, Kenya. Advances in Social Sciences Research Journal, 7(3) 92-112.

MoE \& S- Uganda. (2003). Inclusive education: meeting special and diverse educational needs in an inclusive setting. Kampala: MOE\&S.

Mugenda, A. (2008). Social Science Research. Theory and Principle. Nairobi: Applied Research and Training Services.

Momoh, E. (2010). Uses of improvisation and learning resources in school. European Journal of Educational studies, 4(2), 2012281.

Moodley, S. (2002). Inclusive education: Challenges for distance learning policy and practice. Sydney: Techniko Mugenda, A. (2008). Social Science Research. Theory and Principle. Nairobi: Applied Research and Training Services.

Mugenda, O. and Mugenda, A. (2003). Research Methods: Quantitative and Qualitative Approaches. Nairobi: Acts Press.

National Educational Council for Special Education (NCSE). (2010). Literature Review of the Principles and Practices relating to Inclusive Education for Children with Special Educational Needs. Prepared by Dr. Eileen winter and Paul O’Raw

Ngugi, M. \& Kabuchoru, C. (2009). Introduction to inclusive education. Nairobi: KISE [unpublished]

Mutisya, C, M. S. Factors influencing inclusion of learners with special needs in regular primary schools in Rachuonyo district, Kenya. Unpublished Master's thesis, Kenyatta University.

Lumuba et.al. Teachers Involvement in Creation of Awareness to Members of school community on inclusive Education Practice in Regular primary Schools in Siaya County

Ochieng (2018). Experiences of street - level bureaucrats in the implementation of policies involving access to education by learners living with disability in western Kenya: A case of education offices, school principals and teachers.

Ofsted (2004) Special education needs and disability: towards inclusive schools.

Okech, J.B (2009). Special Needs Education in Uganda. DANIDA/UNISE

Opdal, R. L., Wormnaes, S. and Habayeb, A. (2001) 'Teachers' Opinion about Inclusion: a pilot study in a Palestinian context', International Journal of Disability, Development and Education, Vol.48 (2), pp 143-162

Opuku, E. Bada (2015).Centre for Disability Rehabilitation Studies, Kwame Nkurummah University of Science \& Technology.

Orodho A. J.,\& Kombo.(2002). Essentials of Education and Social Science Research Methods. Nairobi: Masola Publishers.

Orodho, J. A. (2004). Elements of education and social science research methods. Nairobi:Masola publishers.

Orodho, J. A. (2009).Elements of Education and Social Sciences Research Methods. Maseno, Kenya: Kanezja publishers.

Otic Foundation (2007). The Needs of Hearing Impaired People in HongKong. Retrieved from http://www.oticfoundation.org.hk/en/information/information.htm on 16th February,2017.

Owuor O.L. (2014). Determinant of Inclusion of Learners with Special Needs in public primary schools Kisumu municipality, Kisumu County. Thesis. Nairobi University.

Pearce, M. (2009). The inclusive secondary school teacher in Australia. International Journal of Whole Schooling, 5 (2), 1-15.

Pearson, S. (2007). Exploring Inclusive Education: British Journal of Special Education, 34 (1), 25 -32.

Pearson S. (2009) Using activity theory to understand prospective teachers 'attitudes to and construction of Special Educational needs and/or disabilities. Teaching and Teacher Education, 25 (4), 559-568

Polat, F. (2011) 'Inclusion in education: A step towards social justice', International Journal of Educational Development Vol.31 (1), pp 50-58

Poon-McBrayer, K. F. (2004). To integrate or not to integrate: Systemic dilemmas in Hong Kong. The Journal of Special Education, 37(4), 249-256.

Randiki, F. (2002). Historical development of special needs education. Nairobi: KISE.

Republic of Kenya (2005). Kenya Education Sector Support Programme. Nairobi: Government Printer. 
Republic of Kenya (2003), The Persons with Disabilities Act, Nairobi, Government Printer.

Rillotta \& Nettlebeck (2007). Effects of an awareness program on attitudes of students without an intellectual disability towards persons with an intellectual disability.

Ringstaff, Cathy and Kelley, Loretta. (2002). The Learning Return on Our Educational Technology Investment: A Review of Findings from Research. 1-30. WestEd RTEC.

ROK(1988). Education and Manpower Development for this Decade and Beyond. Kamunge report. Nairobi. Government Printers.

Romano, K., \& Chambliss, C. (2002). K-12 Teachers' and Administrators Attitudes Toward Inclusive Educational Practices (Eric Document Reproduction Service No. ED 443 215)

Ross-Hill, R. (2009). Teacher attitude towards inclusion practices and special needs students. Journal of Research in Special Education Needs.

R. W. Karande (2014). School based factors influencing participation of physically challenged learners in public primary schools in Kiambu municipality, Kiambu. Thesis. Nairobi University.

Silverman, J. C. (2007). Epistemological Beliefs and Attitudes Toward Inclusion in Pre-Servie Teachers. Teacher Education and Special Education, 30 (1), 42-51.s

Swart, E. \& Pettipher, R.,( 2005), 'A framework for Understanding inclusion', in E. Landsberg.

Stough, L. M. \& Palmer, D. J. (2003). Special thinking in special settings: a qualitative study of expert special educators. The Journal of Special Education, 36, 2006:22.

The Government of the Republic of Kenya. 2011. National report: Kenya's initial report submitted under article 35(1) of the United Nations Convention on the Rights of Persons with Disabilities. [Online][Accessed 29 December 2013].

Thendu, P. G. (2006). The Influence of Teachers Preparedness on Quality of Teaching HIV/AIDS Curriculum in Primary Schools in Ol Jororok Division, Nyandarua District, Kenya. Unpublished MED Thesis: Kenyatta University.

Thomas, E. (2008). Advances in learning and behavioural disabilities. Bradford,GBR: Emarald group publishers.

Thuo Z.w. (2009). Factors Influencing Implementation of IE in regular primary schools, Kiambu West Division, Kenya. Unpublished MED Report: Nairobi University

Tindall, D. (2013). Department of Physical Education \& Sport Sciences, Univesity of Limerick, Limerick Ireland. Published.

Topping, K. J. (2005). Trends in peer learning, Educational Psychology, 25, 6, 631-6545. .

United Nations Educational, Scientific and Cultural Organization (UNESCO 2008): 'The EFA global monitoring report: Education for all by 2015. Will we make it? Paris: UNESCO. [Online] Available at unesdoc.unesco.org/images/0015/001547/154743e.pdf (Retrieved on 20 July 2014)

UNESCO, (2004). Changing teachers Practices using curriculum Differentiation to respond to students Diversity. 7 places fonorary Paris $-075 \mathrm{Q}$

UNESCO (2005).Guidelines for inclusion: Ensuring access to education for all. Paris.

UNESCO, (2007). EFA Global Monitoring Report: EFA by 2005. Paris: UNESCO.

UNESCO (1994) Access and Quality: World Conference on Special Needs Education, Salamanca, Spain. Paris: UNESCO

UNICEF (2009) Monitoring the situation of children and women.

United Nations Children Fund (UNICEF, Kenya Country Programme 2009-2013). Available [Online] at http:\\www.UNICEF/Kenya /Overview.html (Accessed on 10 October 2012)

United States Department of Education (USDE) 2008.

Vaughn, S.., and Linan - Thompson, S. (2003). What is special about special education for students with learning disabilities? The Journal of Special Education, VOL 37 (3), pp 140 - 147.

Wanganga (2014). Teaching strategies used by teachers to enhance learning to learners with multiple disabilities in four selected counties (Baringo, Kiambu, Kisumu, Nairobi). Thesis. Kenyatta University. 
Obara, D. A., \& Were, C. M. (2020). Teachers` level of support in the use of teaching and learning resources of learners who are physically challenged in regular primary Schools in Kisumu West Sub County, Kenya. Advances in Social Sciences Research Journal, 7(3) 92-112.

Weisman, E. M. and Garza, E.A. (2002) Preservice teacher attitudes toward diversity: One class can make a difference. Equity and Excellence in Education, 35, 28-35

World Bank Report.(2012). Teacher management and development. World development reports. Washington D.C.www.cerebralpalsy.org.au/our-services/education-and-consultancy/just-like-y 